\title{
Living life the natural way - Wheatgrass and Health
}

\section{Satyavati Rana, Jaspreet Kaur Kamboj, and Vandana Gandhi}

Department of Gastroenterology, Post Graduate Institute of Medical Education and Research, Chandigarh, India

Corresponding Author: Prof. Satyavati Rana, House Number 137, Sector 15A, Chandigarh 160015, India, Phone Number (91) 172-2756605

Submission date: August 19, 2011; Acceptance date: November 22, 2011; Publication date: November 30, 2011

\begin{abstract}
:
The Human diet is enriched with young parts of plants (so called "green foods"), which can improve nutrient balance intake in natural way. Wheatgrass (Triticum aestivum) refers to young grass of the common wheat plant, which belongs to Poaceae family. This is the most commonly found herb in India, although its nativity is currently unknown. This plant is believed to have many nutritional values; it has been shown to have anti-inflammatory, antioxidant, anticarcinogenic, immunomodulatory, laxative, astringent, diuretic, antibacterial and anti-aging properties. Its use in acidity, colitis, kidney malfunctions, atherosclerosis and swelling has been shown to be beneficial. Wheatgrass juice helps in building red blood cells and stimulates healthy tissue cell growth. $100 \mathrm{~g}$ of wheatgrass powder is equal to $23 \mathrm{~kg}$ of fresh vegetables. Ideally, wheatgrass should be taken about an hour prior to meal. This allows the body to fully metabolize it without competing with other foods, and it may also curb hunger. It is recommended that lot of water (at least a liter) should be consumed with the juice to reap its maximum nutritional benefits. Taking wheatgrass as a supplement in the mid-morning or mid-afternoon is a great time for this "green" energy boost.
\end{abstract}

Keywords: wheatgrass, anti-carcinogenic, detoxification, health.

\section{INTRODUCTION:}

Throughout human history, plants have played a key role in treating human diseases. In thousands of years of trials, human found many plants which are good for treating ailments and curing serious health problems like cancer, diabetes, and atherosclerosis. They are a kind of alternative medicine that is inexpensive, and has no side effects. For example: wheatgrass, aloe vera, curcumin, alfalfa, garlic, ginger, German chamomile, grapefruit, green tea. In 2002, the U.S. National Center for Complementary and Alternative Medicine of National Institutes of Health began funding clinical trials about the effectiveness of herbal medicines. In 2010, a 
survey of 1000 plants was completed, out of which 356 had clinical trials published evaluating their "pharmacological activities \& therapeutic applications". One of these plants, Wheatgrass, has been an integral part of Indian culture for thousands of years, and has been known to have remarkable healing properties. Scientifically known as Triticum aestivum, it belongs to Poaceae family. Other plants included in this family are: Agopyron cristatum, Bambusa textilis, cynodon dactylon, Poa annua, Zea mays, Aristida purpurea, etc. There is not much scientific data available on these plants because of a lack of substantial research. Therefore, it is important to study their properties to explore their maximum benefits. The cereal grasses- wheatgrass, barley, and alfa-alfa, have been known to boost health and vitality both in humans and animals. Wheatgrass' culms are simple, hollow or pithy, glabrous, and the leaves are approximately $1.2 \mathrm{~m}$ tall, flat, narrow, $20-38 \mathrm{~cm}$ long and $1.3 \mathrm{~cm}$ broad [1]. The spikes are long, slender, dorsally compressed and somewhat flattened (figure 1).

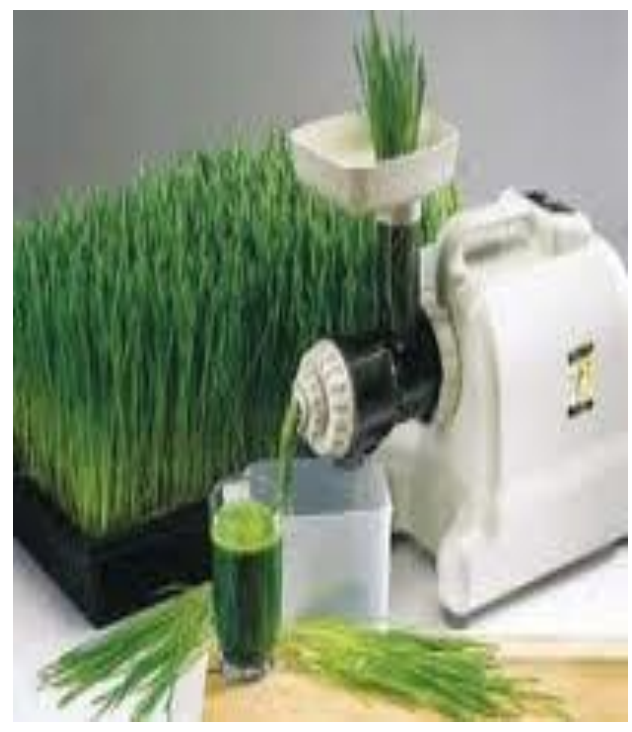

Figure 1. Picture of wheatgrass

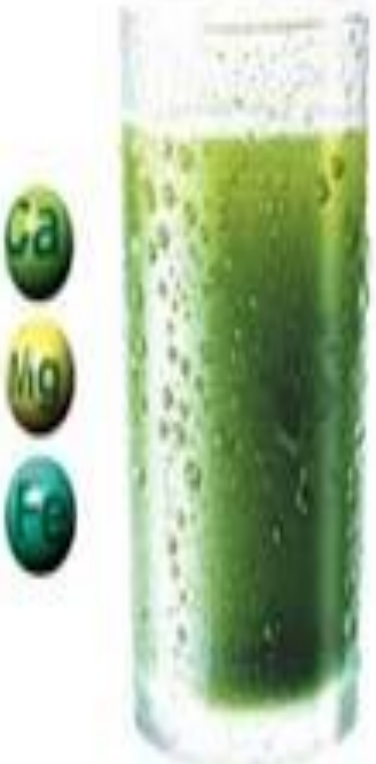

Figure 2. Wheatgrass juice

Wheatgrass is a vegetable, harvested prior to the plant forming the flower head. Wheatgrass packs a nutritional punch, including (per 3.5 grams) $860 \mathrm{mg}$ protein, $18.5 \mathrm{mg}$ chlorophyll, $15 \mathrm{mg}$ calcium, $38 \mathrm{mg}$ lysine, $7.5 \mathrm{mg}$ vitamin $\mathrm{C}$ and an abundance of micronutrients, such as $\mathrm{B}$ complex vitamins and amino acids [2]. Phytochemical constituents of wheatgrass include alkaloids, carbohydrates, saponins, gum and mucilages. Its water soluble extractive value is found to be greater than its alcohol soluble extractive value. This is because of the chlorophyll content of wheatgrass, which is about $70 \%$ water soluble [1]. Wheat grass juice is high in vitamin $\mathrm{K}$, which is a blood-clotting agent. People taking blood-thinning medications or people with wheat-related allergies shouldn't drink wheat grass juice without consulting a health care professional. Wheat allergies are generally a response to the gluten (a protein) found in the wheat berry [2]. Wheatgrass is available in form of extract, tablets (ready to use) and mixed juice (figures-2, 3) 

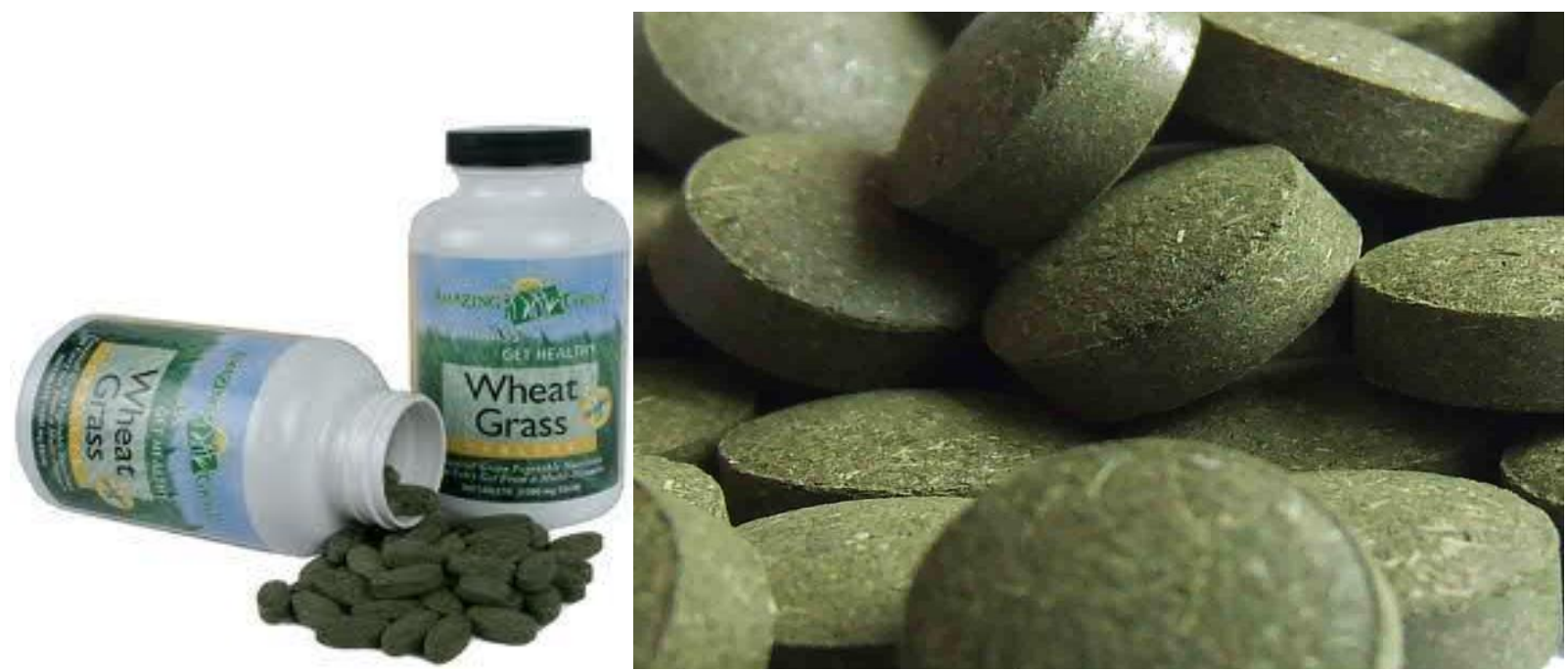

Figure 3. Wheatgrass Tablets

\section{Wheatgrass, Nature's Finest Medicine}

Wheatgrass has been shown to have potential anti-inflammatory and anti-aging properties [3]. Ben et al, DeVogel et al, Ferruzia, and Blakesleeb have reported that regular ingestion of wheatgrass leaf extract improves the digestive system, and promotes general well being [4,5,6]. It has higher nutritive value than broccoli and spinach [7]. Wheatgrass is promoted to treat a number of conditions including the common cold, cough, bronchitis, fever, infections, inflamed mouth and throat, and skin disorders like hemorrhoids, psoriasis, ivy, eczema, burns and thalassemia [8]. A study done by Ben et al has found that patients who were given the extract of wheatgrass showed significant improvement in rectal bleeding and abdominal pain associated with ulcerative colitis, a type of inflammatory bowel disease. The authors gave theories that the flavenoids, anti-inflammatory agents- apigenin and agropyrene contained in wheatgrass, played a role in alleviating symptoms [4]. Another flavenoid present in wheatgrass is Indole, which helps in synthesis of enzymes and deactivating carcinogens in the liver. [9]. The vitamins A, C, E, which are present in wheatgrass, are examples of natural antioxidants. Wheatgrass contains all of the essential amino acids, mainly alanine, aspartic acid, glutamic acid, arginine, serine which are helpful in providing a sufficient amount of protein in the body [10]. Other benefits of wheatgrass are: removal of toxins from the body, improvement of blood sugar balance, prevention of tooth decay, maintainance of healthy hair, aiding digestion, and reducing high blood pressure levels [10].

\section{Hemoglobin and Chlorophyll}

Wheatgrass is rich in chlorophyll and enzymes. It contains more than $70 \%$ chlorophyll (which is an important dietary constituent). The chlorophyll molecule in wheatgrass is almost identical to the hemoglobin in human blood. The only difference is that the central element in chlorophyll is magnesium and in hemoglobin it is iron [11] (Figure 4). The molecular structure of chlorophyll in wheatgrass and hemoglobin in the human body is similar, and because of this wheatgrass is called 'Green Blood' [6]. A 70-83\% increase in red blood cells and hemoglobin concentration 
was noted within 10-16 days of regular administration of chlorophyll derivatives [12]. It was reported that chlorophyll enhanced the formation of blood cells in anemic animals [13]. Chlorophyll is soluble in fat particles, which are absorbed directly into blood via the lymphatic system. In other words, when the "blood" of plants is absorbed in humans it is transformed into human blood, which transports nutrients to every cell of the body. Chlorophyll present in wheatgrass can protect us from carcinogens; it strengthens the cells, detoxifies the liver and blood stream, and chemically neutralizes the polluting elements.
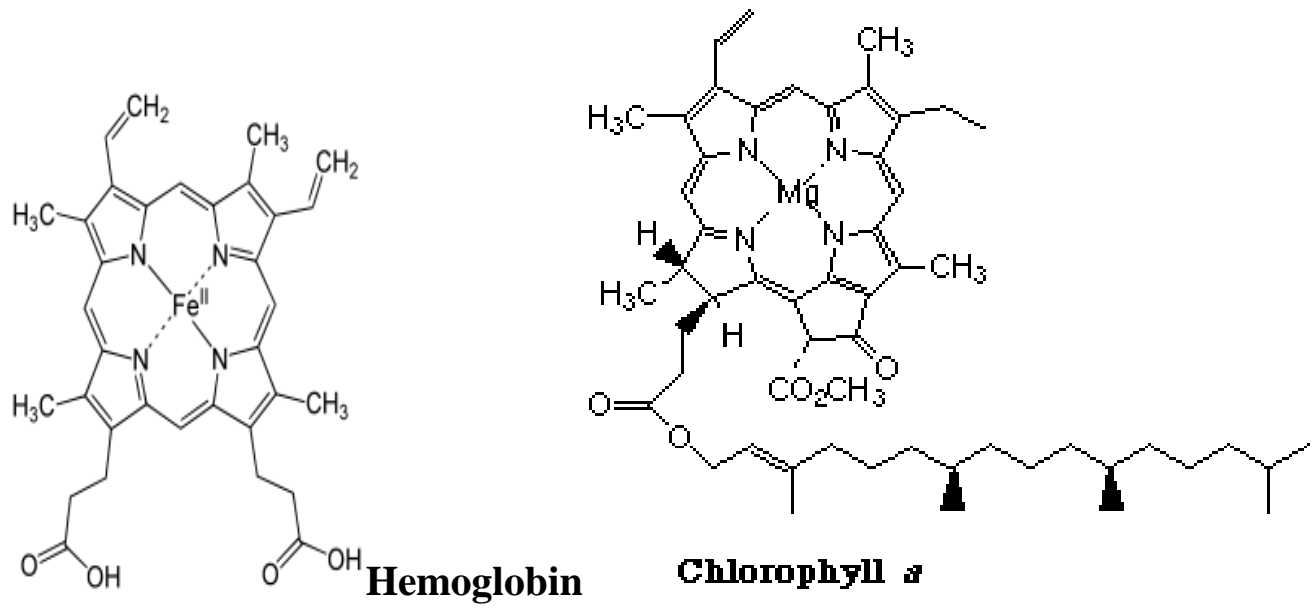

Chlorophyll of

Figure 4. Structure of Hemoglobin and Chlorophyll

\section{Wheatgrass in Cancer prevention}

Environmental factors play an important role in the multistage process of cancer development, and nutritional intervention has been identified to play a very important role in its prevention. Dietary compounds such as garlic, carotenoids, wheatgrass, etc are important due to their antioxidant properties. These dietary products protect against many diseases because food and degraded products come into direct contact with bowel mucosa, and can influence its physiology and metabolism. Although many dietary compounds have been suggested to contribute to the prevention of cancer, there is a strong likelihood that wheatgrass extract, which contains chlorophyll, an antioxidant, may affect cancer prevention. Additionally, selenium and lactrile present in wheatgrass have anti-cancer properties. Selenium builds a strong immune system, and can decrease the risk of cancer [14]. Wheatgrass contains at least 13 vitamins (several of which are antioxidants) including B12, abscisic acid, superoxide dismutase (SOD), cytochrome oxidase, mucopolysaccharide [15]. SOD converts two superoxide anions into a hydrogen peroxide molecule, which has an extra oxygen molecule to kill cancer cells.

Although most people use wheatgrass as a dietary supplement or as serving of vegetables, some proponents claim that a dietary program commonly called wheatgrass diet can cause cancer to regress and extend lives of people with cancer [16]. The true cause of the cancerous degeneration of cells has been revealed to be from the destruction of a specific respiratory enzyme, cytochrome oxidase [17]. $\mathrm{P}_{4} \mathrm{D} 1$, a glycoprotein present in wheatgrass, also acts similarly to antioxidants, stimulating the renewal of RNA and DNA. It is also thought to protect the body 
from the attack of cancer cells by making the walls of cancer cells more open to attack by white blood cells [18]. So, the use of wheatgrass in terminally ill cancer patients should be encouraged $[26,19]$. It was determined that chlorophyll is an active component in wheatgrass extract, which inhibits the metabolic activity of carcinogens [20]. Adjuvant fermented wheatgrass extract (Avemar nutraceutical) improves survival of high-risk skin melanoma patients [21]. Karager et al has concluded that wheatgrass extract inhibits proliferation of 32Dp210 (BCR-ABL fusion gene (+) mouse CML cell line) cells through the induction of apoptosis [22].

Wheatgrass juice may also inhibit hematological toxicity related to chemotherapy in breast cancer patients [23]. It is also observed that people undergoing chemotherapy, who are on wheatgrass, have sailed through this treatment, and have not required hospital admission, while side effects such as nausea, vomiting and mouth ulcers have been virtually non-existent [24].

In another study, in vitro cytotoxic and antiproliferation activities of two extracts-the wheatgrass and the mixture of fibers, were tested and demonstrated anti-leukemia potential with less or no toxic effects towards the healthy immune system. Wheatgrass and fiber methanol extracts have successfully exhibited to be cytotoxic towards HL60 cell lines without causing toxicity towards normal human PBMC. Thus, these health products can be a potential alternative supplement for cancer patients [25].

\section{Hepatoprotective role of wheatgrass}

Triticum aestivum leaf extract affects liver enzyme activities as well as lipid peroxidation [26]. Jain et al reported the hepatoprotective role of fresh wheatgrass juice has in $\mathrm{CCl}_{4}$ treated rats. It showed a significant hepatoprotective effect with a dose of $100 \mathrm{mg} / \mathrm{kg} /$ day in terms of SGOT, SGPT, ALP and Bilirubin in serum [27]. Recently, the hepatoprotective effect of wheatgrass tablets in $\mathrm{CCl}_{4}$ treated rats has been investigated in our lab (unpublished data). Maximum hepatoprotection in this study has been observed with $80 \mathrm{mg} / \mathrm{kg} /$ day dose of wheatgrass tablets. This study indicated that wheatgrass treatment prevented the increase in liver enzymes depending on the dose of wheatgrass [28]. Decreased oxidative stress and increased antioxidant levels have also been observed with wheatgrass treatment [29]. Three compounds (Choline, magnesium and Potassium), found abundantly in wheatgrass, help the liver to stay vital and healthy. Choline works to prevent the deposition of fat. Magnesium helps to draw out excess fat in the same way. Magnesium sulfate (Epsom salts) draws pus from an infection, and potassium acts as an invigorator and stimulant [9].

\section{Wheatgrass as cardio protective and anti- hyperlipidemic agent}

Chlorophyll, abundant in wheatgrass, increases the function of heart. Wheatgrass has been claimed to reduce the blood pressure as it enhances the capillaries, supporting the growth of lactobacilli [30]. Wheatgrass juice has a dilating effect on blood vessels; it makes the blood vessels larger so that blood flows through them more easily. Increased dilation means better nutrition to the cells, and more efficient removal of waste from them. Vitamin E, an antioxidant and fertility vitamin found in wheatgrass is a protector of the heart. This vitamin, present in wheatgrass, is ten times more easily assimilated by the body than synthetic vitamin E. Wheatgrass is a good source of calcium, which helps build strong bones and teeth, and regulates 
heartbeat, in addition to acting as a buffer that restores blood $\mathrm{pH}$. Dried wheatgrass juice has as much calcium as milk [9]. Wheatgrass also contributes $33.26 \mathrm{~g}$ potassium/100g and this mineral plays an important role in regulating fluids and minerals in body cells. This helps in maintaining normal blood pressure and other vital body functions.

An animal study by Kothari et al. found that wheatgrass reduced total cholesterol, LDL, bad cholesterol, and triglyceride levels in rats treated with wheatgrass juice. Triglyceride levels fell by 38 percent in rats given the highest dose of the juice, $10 \mathrm{ml} / \mathrm{kg}$ consumed orally once daily for 21 days, which is equivalent to the results achieved by the common cholesterollowering medication, atorvastatin [30]. A study by Sethi et al found that supplementation with wheatgrass in subjects consuming high-fat diets resulted in the improvement of blood cholesterol levels. This study involved 30 animal subjects; authors had noted that the antioxidant effects of wheatgrass appeared to be responsible for the decreasing of total blood cholesterol levels, and increasing good or HDL cholesterol, as well as the vitamin C blood levels. Therefore, the beneficial role of wheatgrass in ameliorating hyperlipidemia and the associated oxidative stress has also been reported [32, 33].

\section{Wheatgrass - A boon for thalassemia patients}

The $\mathrm{pH}$ factor of human blood is 7.4 and the $\mathrm{pH}$ factor of wheatgrass juice is also 7.4, which is why it is quickly absorbed into blood. Wheatgrass is an effective alternative to blood transfusion. Wheatgrass has the potential to increase the hemoglobin $(\mathrm{Hb})$ levels, increase the interval between blood transfusions, and decrease the amount of total blood transfused in thalassemia Major and intermediate Patients [35, 36]. Wheatgrass sprout extract has been tested for its ability to induce fetal hemoglobin $(\mathrm{HbF})$ production using advanced DNA technology. A rapid 3-5-fold increase has been observed which is "significantly greater than any of the pharmaceutical inducers available". The use of wheatgrass extract may eventually result in an improved quality of life for thalassemics [37]. A pilot study showed that when $100 \mathrm{ml}$ of wheatgrass juice, extracted daily from a 5-6" tall plant, fed to human beings for up to 6 months, was given to 38 thalassemic children, and had beneficial effect on transfusion requirements in 50\% patients of Bthalassemia major. A recent study quoted that wheatgrass tablets, when taken in different numbers in different age groups, showed significant results. 2-3, 6, 8 tablets/day, in divided doses, were given to 40 thalassemia major children aged 1-3 years, 4-8 yrs and 8 or more years respectively. Regular dosage resulted in increased $\mathrm{Hb}$ levels, increased interval between blood transfusions, and decreased amount of blood transfused.

Wheatgrass extract has been effective in reducing activity of ulcerative colitis, and some forms of genetic blood diseases including anemia [38]. Treatment with regenerating green wheatgrass juice is associated with significant reduction in the overall disease activity, and in the severity of rectal bleeding [4]. Animals with low red blood cell counts, when given wheatgrass, had a healthy blood count level within five days. Wheatgrass juice is an effective iron chelator, and its use in reducing serum ferritin should be encouraged in myelodysplastic syndrome and other diseases where repeated blood transfusion is required [39]. Wheatgrass juice is also a complete protein source. Proteins are responsible for an array of diverse functions throughout the 
body ranging from cell renewal and building of hormones, to the repairing of muscles, blood, and organs [34].

\section{Wheatgrass and Diabetes}

The Reduction in the quantity of fibrous foods in modern man's diet is a major cause of many ailments. Supplementing its intake through wheatgrass powder has shown good improvement in resolving digestive system problems, (Diabetes) in particular. Abundance of natural fiber in wheatgrass optimizes blood sugar levels. Instrumental characterization of wheatgrass (spray dried powder of juice) confirmed the presence of chlorophyll, which is believed to be the pharmacologically active component in wheatgrass, acting as an anti-diabetic agent [1]. The hypoglycemic effect of wheatgrass juice in alloxan was induced in diabetic rats, shown by Shaikh et al [40].

\section{Wheatgrass and Rheumatoid Arthritis}

Rheumatoid arthritis affects mainly younger individuals, and is three times more common in females than in males. It can persist into old age, progressively becoming more disabling. Early symptoms include redness, swelling, and soreness of joints. Often joints are affected symmetrically, that is both wrists or knees are involved. Pain and stiffness may also travel to other joints and affect the whole body. In later life, lumps and nodules may appear at the joints and lead to deformities. Patients with rheumatoid arthritis often claim that their symptoms are alleviated by a special diet, or by the simple elimination of certain constituents from their freechoice diet. A study showed that an uncooked vegan diet, rich in lactobacilli, chlorophyll-rich drinks, and increased fiber intake, decreased subjective symptoms of rheumatoid arthritis [41]. Another study showed that when $8.5 \mathrm{~g}$ of fermented wheatgrass extract (Avemar) taken twice per day with water, in case of 15 Severe Rheumatoid Arthritis patients, showed decreased Ritchie index, and according to a health assessment questionnaire, morning stiffness showed significant improvement. Doses of steroids were reduced in half of patients. This may be due to presence of wheatgrass which contains vitamins $\mathrm{A}, \mathrm{B}_{1}, \mathrm{~B}_{2}, \mathrm{~B}_{3}, \mathrm{~B}_{5}, \mathrm{~B}_{6}$ and $\mathrm{B}_{12}$, vitamin $\mathrm{C}, \mathrm{E}$ and $\mathrm{K}$, Calcium, Iodine, Selenium, Zinc, and many other minerals, including, superoxide dismutase, mucopolysaccarides, and chlorophyll. Its anti-inflammatory properties exert a positive effect on bone and joint problems, reducing pain and swelling [42].

\section{Wheatgrass and inflammatory conditions}

Wheatgrass extract (Dr Wheatgrass Skin Recovery Cream), a topical anti-inflammatory immunomodulator, substance $\mathrm{P}$ inhibitor, topical hemostatic agent, and stimulant of fibroblastic activity, with a wide range of healing properties, has been attracting lot of attention; it is also inexpensive. It was observed that wheatgrass cream reduces skin toxicity from radiotherapy [43]. But, another study showed that the topical application of wheatgrass cream is no more effective than a placebo cream for the treatment of chronic plantar fasciitis [44].

Chlorophyllin has bacteriostatic properties that aids in wound healing [45]. It has been used to treat various kinds of skin lesions, burns, and ulcers, where it acts as a wound-healing agent, stimulating granulation tissue and epithelialization [46]. It was reported that rate of 
healing with chlorophyll is so rapid that its inclusion in armamentarium of burn treatment is suggested because it completely supersedes sulphonamide compounds as primary dressing for clean and potentially infected wounds [47].

\section{Wheatgrass and general well being}

Wheatgrass loaded with vitamins A, C, and E acts as an anti-oxidant and retards ageing of cells in the body that causes brain and heart problems. Components of wheatgrass help in making menopause more manageable. Wheatgrass is an effective tonic, beneficial for arthritis, skin allergies, graying or hair loss, weakness, kidney stones, weak eyesight, pyorrhea, or dental infections and fatigue. It is also super effective in serious cases of heart disease, acute stomach ache, infection of digestive system, gas, paralysis, asthma, constipation, diabetes, leucoderma, leukemia, and other cancers [48]. It restores fertility and promotes youthfulness because the high magnesium content in chlorophyll builds enzymes that restore sex hormones. Wheatgrass helps to detoxify the body by breaking impacted matter in the colon. Wheatgrass juice is a fast and sure way to cleanse the body from environmental pollutants. Its high levels of enzymes and amino acids work like a "natural cleanser" to detoxify the liver, eliminate toxic heavy metals from the blood stream, rid the body of waste matter, and slow down the aging process [34].

Wheatgrass and chlorophyll are phytonutrients, which are rich in amino acids, protein, fiber, vitamins, minerals, and enzymes that work mutually to strengthen immunity. It builds up resistance to diseases, eliminates body toxins, and because of its alkaline properties, it is good for urinal problems.

Summary of doses of wheatgrass used in different studies and the outcome has been listed in table 1.

\section{Table 1: Dosages of Wheatgrass used in different studies and the outcome}

\begin{tabular}{|l|l|l|l|l|}
\hline Author & Dose & Disease & $\begin{array}{l}\text { No. of } \\
\text { patients/ } \\
\text { animals }\end{array}$ & Outcome / Benefits \\
\hline $\begin{array}{l}\text { Singh et al, } \\
2010\end{array}$ & $\begin{array}{l}\text { Wheatgrass tablets } \rightarrow 2-3, \\
6,8 \text { tablets/day in divided } \\
\text { doses in children aged 1-3 } \\
\text { yrs, 4-8 yrs \& }>8 \text { yrs } \\
\text { respectively. }\end{array}$ & $\begin{array}{l}\text { Thalasemmia } \\
\text { major children }\end{array}$ & 40 & $\begin{array}{l}\text { Increases Hb level, increases } \\
\text { interval b/w blood transfusions, } \\
\text { decreases amount of blood } \\
\text { transfused. }\end{array}$ \\
\hline $\begin{array}{l}\text { Choudary et al, } \\
2009\end{array}$ & $\begin{array}{l}\text { Wheatgrass tablets at a } \\
\text { dose of 100mg/kg in } \\
\text { divided doses for 6 months } \\
\& \text { 200mg/kg for } \\
1 \text { year if no response at } \\
\text { 6 months }\end{array}$ & $\begin{array}{l}\text { B-Thalasemmia } \\
\text { major }\end{array}$ & 53 & No beneficial effect was observed \\
\hline Marwaha et al & $\begin{array}{l}\text { 100 ml of wheatgrass juice } \\
\text { daily extracted from 5-6" } \\
\text { tall plant fed up to 6 } \\
\text { months in human beings }\end{array}$ & Thalassemia major & 38 & $\begin{array}{l}\text { Wheat grass juice had beneficial } \\
\text { effect on transfusion } \\
\text { requirements in 50\% patients of } \\
\text { B-thalassemia major }\end{array}$ \\
\hline
\end{tabular}




\begin{tabular}{|c|c|c|c|c|}
\hline $\begin{array}{l}\text { Bar Sela et al } \\
\text { (2007) }\end{array}$ & $\begin{array}{l}16 \mathrm{ml} \text { of wheatgrass juice } \\
\text { daily during first } 3 \text { cycles } \\
\text { of chemotherapy }\end{array}$ & $\begin{array}{l}\text { Breast cancer } \\
\text { patients }\end{array}$ & 60 & $\begin{array}{l}\text { Reduces myelotoxicity and } \\
\text { dose of chemotherapy }\end{array}$ \\
\hline $\begin{array}{l}\text { Mukhuopadhyay et } \\
\text { al }\end{array}$ & $\begin{array}{l}\text { 30ml fresh wheatgrass } \\
\text { juice extracted from } 6 \\
\text { week old wheatgrass plant } \\
\text { given for } 6 \text { months }\end{array}$ & $\begin{array}{l}\text { Thalassemia } \\
\text { Intermedia }\end{array}$ & 200 & $\begin{array}{l}\text { It is an effective alternative to } \\
\text { blood transfusion in thalassemia } \\
\text { intermedia patients }\end{array}$ \\
\hline $\begin{array}{l}\text { Wheat et al (2006) } \\
\text { [9] }\end{array}$ & $\begin{array}{l}\text { Wheatgrass extract, }(\underline{\mathrm{Dr}} \\
\text { Wheatgrass Skin Recovery } \\
\underline{\text { Cream })}\end{array}$ & Breast cancer & & $\begin{array}{l}\text { Reduces skin toxicity from } \\
\text { radiotherapy }\end{array}$ \\
\hline Balint et al (2006) & $\begin{array}{l}\text { Fermented wheatgrass } \\
\text { extract (Avemar) } 8.5 \mathrm{~g} \text { of } \\
\text { fermented wheatgrass } \\
\text { extract twice/day+water }\end{array}$ & $\begin{array}{l}\text { Severe Rheumatoid } \\
\text { Arthritis }\end{array}$ & 15 & $\begin{array}{l}\text { Ritchie index decreased \& Health } \\
\text { assessment questionnaire \& } \\
\text { morning stiffness showed } \\
\text { significant improvement. Doses } \\
\text { of steroids reduced in half of } \\
\text { patients. This may be due to } \\
\text { presence of wheat grass contains } \\
\text { vitamins A,B1,B2,B3,B5, B6 and } \\
\text { B12, vitamin C, E and K, } \\
\text { Calcium, Iodine, Selenium, Zinc, } \\
\text { and many other minerals, } \\
\text { superoxide dismutase, muco- } \\
\text { polysaccarides, and chlorophyll. } \\
\text { Its anti-inflammatory properties } \\
\text { exert a positive effect on bone } \\
\text { and joint problems, reducing pain } \\
\text { and swelling. }\end{array}$ \\
\hline $\begin{array}{l}\text { Kulkarni et al } \\
\text { (2006) }\end{array}$ & $\begin{array}{l}\text { 100g wheatgrass for } 15 \\
\text { days }\end{array}$ & Healthy rats & $\begin{array}{l}8 \text { rats in } \\
\text { each } \\
\text { group }\end{array}$ & $\begin{array}{l}\text { highest antioxidant property in } \\
\text { both aqueous and ethanol extract, } \\
250 \% \text { higher potential in } \\
\text { alcoholic as compared to aqueous } \\
\text { extract }\end{array}$ \\
\hline $\begin{array}{l}\text { Ben Arya et al } \\
(2002)\end{array}$ & $\begin{array}{l}\text { 100ml Wheatgrass juice } \\
\text { daily for } 1 \text { month in } \\
\text { ulcerative colitis patients }\end{array}$ & Ulcerative Colitis & 23 & $\begin{array}{l}\text { Severity of rectal bleeding } \\
\text { reduced Disease activity index } \\
\text { decreased }\end{array}$ \\
\hline $\begin{array}{l}\text { http://smilewheatgr } \\
\text { ass.webs.com/direc } \\
\text { tionforuse.html }\end{array}$ & $\begin{array}{l}\text { Wheatgrass in form of } \\
\text { powder } 1 \text { spoon }(3 \mathrm{~g}) \text { per } \\
\text { day for healthy people and } \\
2 \text { spoons for obese patients }\end{array}$ & Obese people & & Weight control \\
\hline
\end{tabular}

\section{Preliminary experimental work from our lab}

1) Wheatgrass was administered orally at different doses of $30 \mathrm{mg}, 40 \mathrm{mg}, 60 \mathrm{mg} \& 80 \mathrm{mg} / 100 \mathrm{~g} \mathrm{~b}$.wt in drinking water for a total duration of 4 weeks along with $\mathrm{CCl}_{4}$ injection given subcutaneously at a dose of $2 \mathrm{ml} / \mathrm{kg}$.bwt twice a week. Wheatgrass dose was started two weeks prior to first injection of $\mathrm{CCl}$. Carbon tetrachloride was administered at a dose of $2 \mathrm{ml} / \mathrm{kg} \mathrm{b}$.wt in control group for 4 weeks and one group was given only wheatgrass at a maximum dose of $80 \mathrm{mg} / 100 \mathrm{~g}$ b.wt/day to check any adverse effect of wheatgrass on liver. The effect to different treatments was studied on serum enzymes like alkaline phosphatase (ALP), aspartate aminotransferase 
(AST) and alanine aminotransferase (ALT) in rats at different time intervals of 2 and 4 weeks and the rat liver was analysed histologically at the end of study. Serum ALP, AST, ALT activity was significantly increased when estimated at the intervals of 2 and 4 weeks. Interestingly, supplementation of wheatgrass to rats helped in regulating the altered activities of ALP, AST and ALT in serum. However, wheatgrass treatment to rats did not indicate any significant change in the activities of all above mentioned liver enzymes at the interval of 2 weeks. This study indicated that wheatgrass treatment prevented the increase in liver enzymes depending on the dose of wheatgrass [28].

2) 18 Wistar rats with body weight of 120-150gms were divided into 3 groups. Group 1: Rats in this group were given normal saline injection subcutaneously twice a week for 4 weeks. Group 2: Carbon tetrachloride was administered subcutaneously at a dose of $2 \mathrm{ml} / \mathrm{kg}$ b.wt twice a week for 4 weeks in this group. Group 3: Wheatgrass was administered orally at $80 \mathrm{mg} / 100 \mathrm{~g}$ b.wt in drinking water for 4 weeks along with $\mathrm{CCl}_{4}$ injection given subcutaneously twice a week at a dose of $2 \mathrm{ml} / \mathrm{kg}$.bwt. Wheatgrass dose was started two weeks prior to first injection of $\mathrm{CCl}_{4}$. Reduced Glutathione (GSH) was measured in liver tissue for antioxidant levels and lipid peroxidation (LPO) for oxidative stress. GSH level was significantly decreased while LPO increased in hepatic tissue of group2 $\left(\mathrm{CCl}_{4}\right.$ treated rats) as compared to group1 (controls).In group3 $\left(\mathrm{CCl}_{4}+\right.$ wheatgrass treated rats), GSH level was increased while LPO decreased as compared to group 2. This study shows that wheatgrass treatment decreased the oxidative stress and increased the antioxidant levels in $\mathrm{CCl}_{4}$ induced hepatotoxicity [29].

\section{CONCLUSION:}

Wheatgrass juice generally contains no harmful substances with the exception of a possible allergic reaction. Wheatgrass is known to help minimize fatigue, improve sleep, increase strength, naturally regulate blood pressure and blood sugar, support weight loss, improve digestion and elimination, support healthy skin, teeth, eyes, muscles and joints, improve the function of our heart-lungs and reproductive organs, heal ulcers and skin sores, slow cellular aging, improve mental function, and is beneficial in arthritis and muscle cramping. It is proven to be beneficial under various conditions, such as anaemia, diabetes, cancer, eczema, constipation, kidney swelling, and common cold. Thus, it should be made part of daily dietary intake in order to explore its maximum benefits.

\section{REFERENCES:}

1. Shirude AA:Phytochemical and pharmacological screening of Wheatgrass ( Triticum Aestivum L.) . International Journal of Pharmaceutical Sciences Review and Research. Volume 9, Issue 1, July 2011,9: issue1,159-164.

2. Wheatgrass wonders. [ http://www.moscowfood.coop/archive/wheat-grass.html].

3. Smith BH: Generalization of spatially variant apodization to nonintegral Nyquist sampling rats. IEEE Trans Image Process 2000, 9:1088-1093.

4. Ben A E, Goldin E, Wengrower D, Stamper A, Kohn R, Berry E: Wheat grass juice in the treatment of active distal ulcerative colitis: a randomized double-blind placebo-controlled trial. Scand J Gastroenterol 2002, 37: 444-449. 
5. DeVogel J, Denize SML, Jonker TM, Katan MB, Meer R van der: Natural chlorophyll but not chlorophyllin prevents heme-induced cytotoxic and hyperproliferative effect in rat colon. J Nutr 2005,135: 1995-00.

6. Ferruzzia MG, Blakesleeb J: Digestion, absorption and cancer preventive activity of dietary chlorophyll derivatives. Nutr Res 2007, 27: 1-12.

7. Meyerowitz S. "Nutrition in Grass"- Wheatgrass Nature's Finest Medicine: The Complete Guide to Using Grass Foods \& Juices to Revitalize Your Health 6th Edition edited by Book Publishing Company; 1999:53.

8. Marwaha RK, Bansal D, Kaur S, Trehan A: Wheat grass juice reduces transfusion requirement in patients with thalassemia major: a pilot study. Indian Pediatrics 2004, 141 : 716-720

9. The Wheatgrass book by Ann Wigmore, Avery publishing group Inc. Wayne, New Jersey

10. James A. Duke. Triticum aestivum L. Handbook of energy crops.

11. Health benefits of wheatgrass juice.[http://www.knowledgebasescript.com/demo/export.php?ID=970\&type=PDF].

12. Kelentei, B., Fekete, I., Kun : Influence of copper chlorophyllin on experimental anemia. Acta Pharm Hung 1958, 28:176-180.

13. Borisenko, A.N., Sofonova, A.D.: Hemopoietic effect of Na chlorophyllin. Vrach Delo 19659:44-46.

14. Scott c: Brain cancer \& wheatgrass [http://www.ehow.com/about_5057457_brain-cancerwheatgrass.html].

15. Ernst E: A primer of complementary and alternative medicine commonly used by cancer patients. Medical J aust 2001, 174:88-92. Clin Exp Rheumatol. 2006 May-Jun;24(3):325-8.

16. Millen AE, Subar AF, Graubard BI, Peters U, Hayes RB, Weissfeld JL, Yokochi LA, Ziegler RG; PLCO Cancer Screening Trial Project Team: Fruit and vegetable intake and prevalence of colorectal adenoma in a cancer screening trial. Am J Clin Nutr. 2007; 86(6):1754-64.

17. Kane DJ, Sarafian TA, Anton R: Bcl-2 inhibition of neural death: decreased generation of reactive oxygen species. Science 1997, 262: 1274-1277.

18. Sandstrom PA, Mannie MD, Buttke TM:Inhibition of activation-induced death in T cell hybridomas by thiol antioxidants:oxidative stress as a mediator of apoptosis. J Leukoc Biol 1994,55: 221-226.

19. Dey S, Sarkar R, Ghosh P, Khatun R, Ghorai K, Choudhury R, Ahmed R, Gupta, P, Mukhopadhyay S, Mukhopadhyay A: Effect of Wheat Grass Juice in Supportive Care of Terminally Ill Cancer Patients - A Tertiary Cancer Centre Experience from India. Journal of Clinical Oncology 2006, 24: s18.

20. Manju V, Balasubramaniyan V, Nalini N: Rat colonic lipid peroxidation and antioxidant status the effects of dietary luteolin on 1, 2-dimethylhydrazine challenge. Cell Mol Biol Lett. 2005, 10: 535-551.

21. Artamonova E, Demidov L, Kharkevitch G, Manziuk L, Pirogova N: Adjuvant fermented Wheatgrass extract (Avemar) nutraceutical improves survival of high-risk skin melanoma patients: a randomized, pilot, phase II clinical study with a 7-year follow-up. Cancer Biotherapy Radiopharmaceuticals 2008, Vol23.4:(5):669.

22. Karadag A, Ozkan T, Altinok B, Aydos S, Sunguroglu A: Antiproliferative and apoptotic effects of wheatgrass (Triticum aestivum L.) extracts on chronic myeloid leukemia (CML) cell line. Planta Med. 2007, 73:897-899.

23. BarSela G, Tsalic M, Fried G, Goldberg H: Wheat grass juice may improve hematological toxicity related to chemotherapy in breast cancer patients. Nutr Cancer. 2007, 58(1): 43-48. 
24. Cassileth BR, Lusk EJ, Guerry D, Blake AD, Walsh WP, Kascius L, Schultz DJ: Survival and quality of life among patients receiving unproven as compared with conventional cancer therapy. N Engl J Med. 1991 Apr 25;324(17):1180-5.

25. Noorjahan Banu Alitheen*, Chuah Li Oon, Yeap Swee Keong, Tan Kee Chuan, Ho Ket Li And Ho Wan Yong: Cytotoxic Effects Of Commercial Wheatgrass And Fiber Towards Human Acute Promyelocytic Leukemia Cells (H160). Pak. J. Pharm. Sci. 2011, 24(3): 243250.

26. Arya P, Kumar M: Chemoprevention by Triticum Aestivum of Mouse Skin Carcinogenesis Induced by DMBA and Croton Oil - Association with Oxidative Status. Asian Pacific J Cancer Prev, 2011, 12:143-148.

27. Jain G, Argal A, Pathak A.K, Singh V.K, Kannojia P: Hepatoprotective activity of wheatgrass juice. The pharmacist 2007, 2(1) 29-30.

28. Kamboj J K, Rana S V, Dhawan D K,Vahiphei K: Role of wheatgrass in prevention of carbon tetrachloride induced hepatotoxicity in rats [abstract ]. J. Clinical and Experimental Hepatology 2011, 1:S1.

29. Kamboj J K, Rana S V, Ola R P , Dhawan D K , Vahiphei K: Wheatgrass and antioxidant levels in carbon tetrachloride induced hepatotoxicity in rats [abstract]. ]. J. Clinical and Experimental Hepatology 2011, 1:S1.

30. Locniskar M. (1988). Nutrition today. 3:37.

31. Saroj Kothari, Anand K Jain, Swaroop C Mehta, Shrinivas D Tonpay: Effect of fresh Triticum aestivum grass juice on lipid profile of normal rats. 2008, 40(5) : 235-236.

32. Sethi J, Yadav M, Dahiya K, Sood S, Singh V, Bhattacharya SB: Antioxidant effect of Triticum aestivium (wheat grass) in high-fat diet-induced oxidative stress in rabbits. Methods Find Exp Clin Pharmacol. 2010, 32(4):233-235.

33. Zelina, Iknur SM, Ismat O, Yetkin Y, Ibrum GO: The Investigation of the Antioxidative Properties organoselenium Compound in Some Rat Tissues. Experi Bio and Med. 2008, 233: 575-579.

34. Wheat J, Currie J: Herbal medicine for cancer patients: An evidence based review. The Internet Journal of Alternative Medicine 2008, 5: 28-30

35. Wheatgrass juice benefits [http://www.smoothiekingphoenix.com/files/articles/Wheatgrass_Juice_Benefits.pdf]

36. Singh K, Pannu MS, Singh P, Singh J: Effect of wheat grass tablets on the frequency of blood transfusions in Thalassemia Major. Indian J Pediatr Jan 2010, 77(1):90-101.

37. Mukhopadhyay S, Dey S, Gupta P and Mukhopadhyay A: Effect of wheat grass juice in supportive care of terminally ill solid organ cancer patients: Experience from eastern India [abstract]. Cancer Prevention Research 2008, 1: s7.

38. Wheatgrass - $\quad$ Effective Inducer Of Fetal Hemoglobin. [Http://Www.Drwheatgrass.Com/Default.Aspx]

39. Grunewald J. Novel Botanical Ingredients For Beverages. Clinics For Dermatology 2009, 27 : 210-216.

40. Mukhopadhyay S, Basak J, Kar M, Mandal S, Mukhopadhyay A:The Role Of Iron Chelation Activity Of Wheat Grass Juice In Patients With Myelodysplastic Syndrome. J. Clin. Oncology 2009, 7012-7014.

41. Shaikh M, Quazi M, Nandedkar R.: Hypoglycemic Effect Of Wheatgrass Juice In Alloxan Induced Diabetic Rats. Pharma Tutor 2011 ,Pg 10

42. T. Nenonen,. Helve T, Rauma T, Nninen H: uncooked, Lactobacilli-Rich, Vegan Food And Rheumatoid arthritis. British Journal Of Rheumatology 1998; 37:274-281. 
43. Bálint G, Apáthy A, Gaál M, Telekes A, Resetár A, Blazsó G, Falkay G, Szende B, Paksy A, Ehrenfeld M, Shoenfeld Y, Hidvégi M : Effect of Avemar--a fermented wheat germ extract--on rheumatoid arthritis. Preliminary data. Clin Exp Rheumatol 2006; 24(3):325-8.

44. Wheat J, Currie G, Coulter K: Wheatgrass extract as a topical skin agent for acute radiation skin toxicity in breast radiation therapy: A randomized controlled trial. J. Aust. Trad. Med. Soc. 2006, 12(3):135-37.

45. Young MA, Cook JL, Webster KE: The effect of topical wheatgrass cream on chronic plantar fasciitis: a randomized, double-blind, placebo-controlled trial. Complement Ther Med. 2006, 14(1):3-9.

46. Chernomorsky SA, Segelman AB : Biological activities of chlorophyll derivatives. N J Med. 1988, 85(8):669-73.

47. Grunewald J: Novel Botanical ingredients for beverages. Clinics for Dermatology 2009, 27 : 210-216.

48. Fahey, Jed W, Katherine K, Stephenson, Albena T, Kostova D, Patricia A, Egner, Thomas W, Kensler and Talalay P: "Chlorophyll, chlorophyllin and related tetrapyrroles are significant inducers of mammalian phase 2 cytoprotective genes". Carcinogenesis (Oxford University Press) 2005,6 (7): 1247-1255. 